\title{
Correlation of Soil Properties with Weed Ocurrence in SUgarcane AREAS ${ }^{1}$
}

\author{
Correlação de Atributos do Solo com a Ocorrência de Plantas Daninhas em Áreas de Cana-de- \\ Açúcar
}

\author{
LOUSADA, L.L. ${ }^{2}$, FREITAS, S.P. ${ }^{2}$, MARCIANO, C.R. ${ }^{2}$, ESTEVES, B.S. ${ }^{2}$, MUNIZ, R.A. ${ }^{3}$, and \\ SIQUEIRA, D.P. ${ }^{2}$
}

\begin{abstract}
Soil properties can influence weed community composition and weed density agricultural area. Knowing this relationship would allow to choose the best strategy for the control of such plants. This study aimed to investigate the correlation between weed density and chemical and physical attributes of soil in three areas (UCO, USC, and UPA) for commercial sugarcane cultivation in Campos dos Goytacazes, RJ. Grids of $40 \mathrm{~m}$ x $40 \mathrm{~m}$ were established in the areas, and soil samples were collected at the intersection points for physical and chemical analysis and evaluation of the soil seed bank (SSB), followed by a phyto-sociological survey of the weeds present. Samples were collected during two periods: February/March and June/July, 2010. SSB presented the greatest number of species per vegetation evaluated in the two sampling periods. Clay content had a positive effect leading to greater weed density in all areas (UCO, USC and UPA) in at least one of the densities $(0-10$ and $10-20 \mathrm{~cm})$. On the other hand, sand content, when significant, presented a negative correlation with plant density in all the SSB areas analyzed. The $\mathrm{pH}$ negatively influenced the density of the species found through the phyto-sociological survey at USC and UPA. Cyperus rotundus, dominant in all areas, correlated positively with phosphorus, potassium, and clay content and negatively with $\mathrm{pH}$ and high sand content.
\end{abstract}

Keywords: soil physics, soil chemistry, seed bank, phyto-sociological survey.

RESUMO - Os atributos do solo podem influenciar na composição da comunidade infestante e densidade de plantas daninhas da área agricola; conhecer essa relação permitiria a escolha da melhor estratégia para o controle dessas plantas. Este trabalho objetivou investigar a correlação entre densidade de plantas daninhas e atributos quimicos e físicos do solo, em três áreas (UCO, USC e UPA) de cultivo comercial de cana-de-açúcar, no Município de Campos dos Goytacazes-RJ. Nas áreas foram estabelecidas grades de $40 \times 40 \mathrm{~m}$, sendo coletadas, nos pontos de interseção, amostras de solo, para análise física e quimica e avaliação do banco de sementes do solo (BSS); ainda, foi realizado o levantamento fitossociológico das plantas daninhas presentes nos pontos. As coletas foram feitas em dois periodos: fevereiro/março e junho/julho de 2010. O BSS apresentou maior número de espécies em relação à vegetação avaliada, nos dois periodos de coleta. O teor de argila influenciou positivamente a maior densidade de plantas daninhas em todas as áreas (UCO, USC e UPA), em pelo menos uma das profundidades (0-10 e 10-20 cm). Em contraponto, o teor de areia apresentou correlação, quando significativa, negativa com a densidade de plantas do BSS nas áreas analisadas. $\mathrm{O}$ pH influenciou negativamente a densidade de espécies encontradas durante $O$ levantamento fitossociológico na USC e UPA. A espécie Cyperus rotundus, dominante no levantamento fitossociológico em todas as áreas, correlacionou-se positivamente com o fósforo, potássio e teor de argila e negativamente com o $\mathrm{pH}$ e alto teor de areia.

Palavras-chave: física do solo, química do solo, banco de sementes do solo, levantamento fitossociológico.

1 Recebido para publicação em 15.10.2012 e aprovado em 22.1.2013.

Parte da Dissertação de Mestrado em Produção Vegetal Centro de Ciências e Tecnologias Agropecuárias da Universidade Estadual do Norte Fluminense Darcy Ribeiro - CCTA/UENF

2 Universidade Estadual do Norte Fluminense, Campos dos Goytacazes-RJ, Brasil, <delimalousada@yahoo.com.br>; ${ }^{3}$ Escola Superior de Agricultura “Luiz de Queiroz”, USP, Piracicaba-SP, Brasil. 


\section{INTRODUTION}

The growing concern over the search for renewable and cleaner energy sources has increased the demand for biofuels, among which stands out the Ethanol from sugarcane. Thus, the cultivation area has expanded itself, especially in South-Central Brazil (Almeida et al., 2008). Although the sugarcane industry of the state of Rio de Janeiro has followed the national growth of this sector in recent years, as demonstrated by Mendonça et al. (2011), the productivity of this region is below the national average and one of the contributing factors is the weed interference.

Weed strategies allow it to stay in cultivated areas for generations, and the soil seed banks (SSB) formation is one of them. Many species have high seed production, which allows the gradual increase of the SSB (Boguzas et al., 2004), which hampers its eradication. Thus, knowing the most harmful species present in cultivation areas is extremely important for the development of an efficient management, since their presence may result in large losses during the production cycle.

Weed is not distributed uniformly along the ground, and the spatial variability of the infestation is observed, with stains or thick woods formations (Izquierdo et al., 2009; Iwara et al., 2011). The physical, chemical and biological soil properties also present spatial variability, assuming similar values to short distances and different values as the distance between observations increases. The spatial variability that soil properties and weed present occurs due to several factors, among which are: topography, structure and type of soil, groundwater characteristics, microclimate and management practices (Silva et al. 2008).

The dynamics and the development of weed SSB vary according to time of year, the crop stage and edaphic conditions. Although climatic factors usually influence the distribution of species on a large scale, soil factors are considered the most influential (Otto et al., 2007), as it can change the growth of certain species and explain their presence and relative abundance in certain locations of the cultivated areas (Walter et al., 2002; \& Shaukat Siddiqui, 2004; Udoh et al., 2007; Iwara et al., 2011; Gomaa, 2012). Taking it into consideration, it is necessary to know which factors may be related, directly or indirectly, and determining the occurrence of some weed species, since, with such information, it would be possible to schedule a more appropriate management.

In this context, knowing the soil seed bank and from phyto-sociological surveys, we sought to investigate the relation between weed density and the chemical and physical soil properties (macronutrients, aluminum, CTC and $\mathrm{pH}$, granulometry) in sugarcane production areas in the northern region of the state of Rio de Janeiro.

\section{MATERIALS AND METHODS}

\section{Description of the study area}

This study was developed in the sugarcane commercial cultivation in three sugar and alcohol production plants, in Campos dos Goytacazes, in the northern region of the state of Rio de Janeiro. The areas studied belong to the following plants: COAGRO - Cooperativa Agroindustrial do Estado do Rio de Janeiro (UCO), Santa Cruz (USC) and Paraíso (UPA). The soil of the three areas was classified as Cambisol, according to data from Projeto de Irrigação e Drenagem da cana-de-açúcar da Região Norte Fluminense (PROJIR, 1983), provided by Universidade Federal Rural do Rio de Janeiro (UFRRJ), Dr. Leonel Miranda Campus.

According to the Köppen system, the climate of this region is classified as Aw, with hot and humid weather, the coldest month temperature above $18{ }^{\circ} \mathrm{C}$ and average annual temperature around $24{ }^{\circ} \mathrm{C}$. The average annual rainfall is around $1,023 \mathrm{~mm}$, mainly from October to January.

The sampling area used at COAGRO plant comprised 4.0 hectares, between longitude 4716’27" West and latitude 2148'15" South. The species planted in this area was SP81325, which was found in the third section, and the following herbicides were applied: Ametrine, MSMA and Nortox. 
At USC the sampling area used comprised 2.7 hectares, between longitude $47^{\circ} 25^{\prime} 24^{\prime \prime}$ West and latitude $21^{\circ} 44^{\prime} 41^{\prime \prime}$ South. The species planted in this area was SP792233, which was found in the sixth section, and the following herbicides were applied: Combine and Provence.

The sampling area used at UPA comprised 2.0 hectares, between longitude $47^{\circ} 23^{\prime} 44^{\prime \prime}$ West and latitude $21^{\circ} 38^{\prime} 39^{\prime \prime}$ South. The species planted in this area was RB867515, which was found in the second section, and the following herbicides were applied: Velpar K e Gamit.

\section{Weed sampling}

The sampling areas were divided into grids, equidistant, $40 \times 40 \mathrm{~m}$, where each intersection in the grid represented a collection point, divided as follows: 25 points to UCO, 16 points to USC and 12 points to UPA. All points were geo-referenced with GPS (Garmin 60cSX Map model, GPS Track Maker software) and staked for their marking.

Field samples were collected in 2010 into two periods: February/March (season 1) and June/July (season 2). The weed density (number of individuals/area) found in the cultivated areas was obtained through soil seed bank (SSB) and phyto-sociological survey.

\section{Phyto-sociological survey}

The phyto-sociological survey was conducted with the aid of square template $0.5 \times 0.5 \mathrm{~m}$, launched in the vicinity of the point. Plants were cut at ground level, stored in plastic bags and taken to the laboratory where they were quantified and identified by means of literature (Lorenzi, 2000) and through comparisons with herbarium material. The absolute and relative frequencies, densities and dominances of weed species were analyzed. The importance value index (IVI) was also evaluated, which numerically expresses the importance of a particular species in a community; both procedures were performed according to Mueller-Dombois \& Ellenberg (1974).

\section{Soil seed bank (SSB)}

For SSB collection, a circular sampler of area $165 \mathrm{~cm}^{2}$ and cutting blade height of
$10 \mathrm{~cm}$ was used, and two depths $(0$ to $10 \mathrm{~cm}$ and 10 to $20 \mathrm{~cm}$ ) were sampled for each point. Field samples were placed in plastic bags, labeled and transported to the greenhouse at Unidade de Apoio à Pesquisa do Centro de Ciências e Tecnologias Agropecuárias (UAP/ CCTA) of UENF. Then, soil samples were placed in plastic trays, numbered and separated according to the location of the geo-referenced point and then placed on benches. The lateral dimensions of the trays were $32.5 \times 20 \mathrm{~cm}$, and the soil layer height was $5 \mathrm{~cm}$. Irrigation was performed twice a day (for 20 minutes on hot days, and 10 minutes on warm or cold days) through micro-sprinklers inside the greenhouse, controlled by a timer. The light inside the greenhouse was controlled with the use of $50 \%$ shading material. The trays were previously perforated, so that there was not water accumulation.

Quantification of BSS was performed by means of direct counting of emerged seedlings method, according to the methodology proposed by Monquero et al. (2008). The samples were evaluated in three streams of emergency, at 40,80 and 120 days for each collection season, and the trial period in the greenhouse occurred from February to October 2010. At each flow seedlings were identified, recorded and later emoved for disposal. The identification was performed with the aid of specialized literature (Lorenzi 2000). When it was not possible to identify some seedlings, some of their specimens were transplanted to pots with PLANTMAX ${ }^{\circledR}$, so that during their development they should be recognized.

\section{Soil analysis}

The soil samples used in the chemical and physical analyzes were collected simultaneously with BSS samples. Physical analyses were performed to obtain sand, silt and clay. Chemical analyses of soil were performed to obtain concentrations of calcium $(\mathrm{Ca})$, magnesium $(\mathrm{Mg})$, potassium $(\mathrm{K})$, phosphorus $(\mathrm{P})$, sodium $(\mathrm{Na})$, aluminum $(\mathrm{Al})$, carbon $(\mathrm{C})$, cationic exchange capacity (CEC) and $\mathrm{pH}$. All analyzes were performed according to Embrapa (1997), and the summary of results is presented in Table 1 . 
Table 1 - Soil properties values - minimum (min), medium (med) and maximum (max) obtained to sugarcane commercial cultivation areas at COAGRO (UCO), Santa Cruz (USC) and Paraíso (UPA) plants in Campos, Rio de Janeiro, in 2010

\begin{tabular}{|c|c|c|c|c|c|c|c|c|c|c|c|c|}
\hline \multirow{2}{*}{$\begin{array}{c}\text { Layer } \\
(\mathrm{cm})\end{array}$} & \multicolumn{3}{|c|}{$\mathrm{pH}$} & \multicolumn{3}{|c|}{$\mathrm{P}\left(\mathrm{mg} \mathrm{dm}^{-3}\right)$} & \multicolumn{3}{|c|}{$\mathrm{K}\left(\mathrm{mg} \mathrm{dm}^{-3}\right)$} & \multicolumn{3}{|c|}{$\mathrm{C}\left(\mathrm{g} \mathrm{dm}^{-3}\right)$} \\
\hline & Min & Med & Max & Min & Med & Max & Min & Med & Max & Min & Med & Max \\
\hline \multicolumn{13}{|c|}{$\mathrm{UCO}$} \\
\hline $0-10$ & 5.4 & 5.9 & 6.3 & 2.0 & 5.2 & 12.0 & 1.3 & 14.1 & 22.0 & 12.8 & 20.1 & 24.6 \\
\hline $10-20$ & 5.4 & 6.0 & 6.5 & 3.0 & 6.4 & 16.0 & 1.2 & 13.1 & 19.8 & 12.4 & 19.1 & 23.8 \\
\hline \multicolumn{13}{|c|}{ USC } \\
\hline $0-10$ & 5.6 & 5.9 & 6.3 & 3.0 & 12.8 & 40.0 & 4.2 & 6.6 & 12.1 & 15.6 & 18.0 & 23.8 \\
\hline $10-20$ & 5.9 & 6.2 & 6.5 & 3.0 & 7.4 & 27.0 & 2.1 & 3.8 & 5.6 & 14.5 & 15.9 & 18.6 \\
\hline \multicolumn{13}{|c|}{ UPA } \\
\hline $0-10$ & 5.8 & 6.3 & 6.7 & 3.0 & 15.6 & 6.6 & 0.8 & 2.6 & 4.6 & 18.4 & 23.8 & 30.0 \\
\hline $10-20$ & 5.9 & 6.4 & 6.7 & 2.0 & 10.8 & 40.0 & 0.8 & 1.84 & 4.2 & 18.0 & 22.7 & 26.8 \\
\hline Layer & \multicolumn{3}{|c|}{$\mathrm{CTC}\left(\mathrm{cmol}_{\mathrm{c}} \mathrm{dm}^{-3}\right)$} & \multicolumn{3}{|c|}{ Areia (\%) } & \multicolumn{3}{|c|}{ Silte $(\%)$} & \multicolumn{3}{|c|}{ Argila (\%) } \\
\hline$(\mathrm{cm})$ & Min & Med & Max & Min & Med & Max & Min & Med & Max & Min & Med & Max \\
\hline \multicolumn{13}{|c|}{$\mathrm{UCO}$} \\
\hline $0-10$ & 97.3 & 131.4 & 176.0 & 4.6 & 11.5 & 23.9 & 30.3 & 39.8 & 50.4 & 37.6 & 48.7 & 56.6 \\
\hline $10-20$ & 92.4 & 116.1 & 147.7 & 4.8 & 11.7 & 27.8 & 28.8 & 40.0 & 58.5 & 31.7 & 48.2 & 57.3 \\
\hline \multicolumn{13}{|c|}{ USC } \\
\hline $0-10$ & 76.3 & 86.9 & 105.2 & 13.8 & 29.1 & 42.7 & 26.2 & 34.5 & 41.9 & 29.1 & 36.5 & 44.3 \\
\hline $10-20$ & 74.6 & 92.3 & 104.7 & 12.9 & 28.1 & 40.9 & 26.6 & 34.6 & 42.9 & 31.1 & 37.2 & 44.2 \\
\hline \multicolumn{13}{|c|}{ UPA } \\
\hline $0-10$ & 103.7 & 148.1 & 208.1 & 6.2 & 19.4 & 45.0 & 21.9 & 27.2 & 33.5 & 39.6 & 57.6 & 73.0 \\
\hline $10-20$ & 96.5 & 142.1 & 173.3 & 5.15 & 15.4 & 35.9 & 22.2 & 26.3 & 35.2 & 37.4 & 58.3 & 68.1 \\
\hline
\end{tabular}

\section{Data analysis}

Within each season, the possible relation between weed density found through phytosociological and through BSS with the physical and chemical properties were evaluated by Spearman's rank correlation coefficient (c). From each sample point two species that had the highest importance value index (IVI) in both survey and in BSS were highlighted, aiming to determine if the occurrence of these species would be correlated with the soil properties analyzed. The correlation study was made from each sampled point, indicating if it occurred and if it was positive or negative. Correlations with a significance level lesser than 5\% $(p<0.05)$ were considered as significant and those with significant level lesser than $1 \%$ $(p<0.01)$, as highly significant.

The similarity between the composition of SSB and the weed phyto-sociological survey was studied by Sorensen similarity index (SI), described in Oliveira \& Freitas (2008), shown in Equation 1.

$$
I S=\left(2 A^{*}(B+C)-1\right) * 100
$$

where $A=$ number of common species between SSB and spontaneous vegetation, $B=$ number of species BSS and $C=$ number of species in spontaneous vegetation.

\section{RESULTS AND DISCUSSION}

\section{Correlation between weed found in SSB and phyto-sociological survey}

In the phyto-sociological survey performed during season 1,15 weed species were identified at UCO, 12 at UPA and 10 at USC. At UCO and USC, the highest IVI values were found in species Cyperus rotundus (144 and 194, respectively) and Rottboellia cochinchinensis (86 and 64, respectively). At UPA the highest IVI was observed in species Phyllanthus niruri (130) and Commelina erecta (63). Oliveira \& Freitas (2008), performing a phyto-sociological study on sugarcane culture in Campos dos Goytacazes also found the highest IVI values in C. rotundus and $R$. cochinchinensis, but the authors did not observe the presence of species Phyllanthus niruri and Commelina erecta during the same period of the year and in the same soil type (Cambisol).

More species were found in the SSB area evaluation in season 1 , in relation to those found in phyto-sociological survey, 38 species 
occurring at UCO, 25 at USC and 24 at UPA. This result contrasts some studies performed in different management systems and climatic conditions (Shaukat \& Siddiqui, 2004; Gomaa, 2012), which has found more species in the phyto-sociological survey than in SSB. However, the result of this study emphasizes the importance of knowledge of SSB in cultivation areas because it represents its management history and it can be used as a database for future infestation potential of the area, which can be expressed according to favorable environmental conditions (Lopes et al., 2004).

Regarding the occurrence of common species between SSB and spontaneous vegetation, during season 1,10 species were found at UCO and 6 at USC and UPA. Comparing natural vegetation and the area SSB by Sorensen similarity index, it can be seen that the correlations found are low (Table 2). While SSB evaluation is performed under controlled and proper environmental conditions for plant germination (being, therefore, a weed infestation potential measure), phytosociologic evaluation result is influenced by environmental conditions and/or by synergistic or antagonistic interactions with the interest culture, which often deviate from the ideal condition for the full establishment and development of plants. Isaac \& Guimarães (2008), analyzing the relation between the species found during the phyto-sociological survey and the SSB in two cultivation systems, conventional and direct sowing system, found a similarity index of 0.35 - a value close to the ones obtained in this study.

In the phyto-sociological survey of season 2, 19 weed species were collected and identified at UCO, 17 at USC, and 12 at UPA. At UCO and UPA the highest IVI values were presented by

Table 2 - Sorensen similarity index between weed found in soil seed bank (SSB) and in phyto-sociological survey (PSS) at COAGRO (UCO), Santa Cruz (USC) and Paraíso (UPA) plants in Campos dos Goytacazes, corresponding to the collection time in February/March (season 1) and June/July (season 2)

\begin{tabular}{|c|c|c|c|}
\hline \multirow{2}{*}{ Comparison } & \multicolumn{3}{|c|}{ Areas } \\
\cline { 2 - 4 } & UCO & USC & UPA \\
\hline SSB x PSS (season 1) & 0.37 & 0.34 & 0.33 \\
\hline SSB x PSS (season 2) & 0.40 & 0.51 & 0.25 \\
\hline
\end{tabular}

species C. rotundus (127 and 123, respectively) and Sorghum halepense (46 and 201, respectively) and at USC by species C. rotundus (120), and Indigofera truxillensis (29). Duarte Júnior et al. (2009) evaluating the weed dynamics in the sugarcane crop in Campos dos Goytacazes, found the highest IVI values in C. rotundus and S. halepense, during March/July season.

As for SSB, during season 2, similarly to what happened in season 1 , more species in the phyto-sociological survey in the three areas were found, 31 species occurring at UCO, 22 at USC and 19 at UPA. It may be noted, however, that the number of species present in SSB in the three areas was lower in season 2 , while in the phyto-sociological survey of two areas (UCO and USC) the opposite was noted, that is, there was an increase in the number of species in this season (at UPA there was no change). The lowest number of species obtained in the phyto-sociological field survey in season 1 may be related to the occurrence of a long period without rain and with high average daily temperatures (approximately $30{ }^{\circ} \mathrm{C}$ ) in January and February. In season 2 there was more regular rainfall and previous temperatures remained relatively high (about $25^{\circ} \mathrm{C}$ in May and between 20 and $25^{\circ} \mathrm{C}$ in June), favoring the emergence of a greater number of species, as observed.

At UCO and USC 10 common species were found between spontaneous vegetation and $\mathrm{SSB}$, and four common species were found at UPA, during season 2 (Table 2).

Kuva et al. (2008) analyzed the similarity between the weed species found from SSB and phyto-sociological survey in three different seasons and obtained low coefficients of 0.38 , 0.29 and 0.33 , respectively, concluding that there is no variation in relation to seasons. In contrast, the results obtained in this study indicated that the collection season influenced the number of species and the BSS density and species density found in the phyto-sociological survey of the areas analyzed.

\section{Correlation between the seed bank and the physical and chemical soil}

By performing correlation analysis for soil chemical properties, it was found that some of them did not show any significant 
correlation with density or weed species. Thus, in the correlations shown, properties that indicated any positive or negative correlation were selected.

As for plant density in SSB, during season 1 at UCO, positive correlations with clay content ( $c=0.481, \mathrm{p}<0.01)$ were observed at a depth of $0-10 \mathrm{~cm}, \mathrm{C}(c=0.596, \mathrm{p}<0.01)$ and with CTC $(c=0.407, \mathrm{p}<0.05)$ and a negative correlation with sand content $(c=-0.559, \mathrm{p}<0.01)$ (Table $3)$. At a depth of $10-20 \mathrm{~cm}$ no significant correlations were found.

Unlike observed at UCO, USC and UPA, only significant correlations were observed at a depth of $10-20 \mathrm{~cm}$ from soil. At USC, only a positive correlation with clay content was observed $(c=0.651, \mathrm{p}<0.01)$. At UPA, a positive correlation with $\mathrm{K}(c=0.807, \mathrm{p}<0.01)$, $\mathrm{C}(c=0.717, \mathrm{p}<0.01)$ and with clay content $(c=0.715, \mathrm{p}<0.01)$ and a negative correlation with sand content $(c=-0.701, \mathrm{p}<0.05)$ were observed. Walter et al. (2002), evaluating the relation between physical and chemical soil properties and weed density in SSB, observed that the species Stellaria media density was positively influenced by clay content and negatively influenced by sand content. According to these authors, soil properties can influence weed growth. Gaston et al. (2001), evaluating the spatial variability of soil and weed properties in the Mississippi Delta, observed that sandy texture areas showed low weed density and they were practically free of them during two years, while clayey texture areas showed high weed density. From these results, the authors found that the higher clay content the higher recurrence of certain weed in these areas, requiring a more efficient control of these sites.

During season 2, significant correlations between soil properties and weed density in SSB at both depths (Table 4) were observed in the three areas analyzed. At UCO, at the $0-10 \mathrm{~cm}$ layer, positive correlations with $\mathrm{P}$ and with clay content $(c=0.412, \mathrm{p}<0.05$ and $c=0.339, \mathrm{p}<0.05$, respectively) were observed. At the $10-20 \mathrm{~cm}$ layer, a positive correlation with CTC and with clay content $(c=0.403$, $\mathrm{p}<0.05$ and $c=0.475, \mathrm{p}<0.01$, respectively) and a negative correlation with silt content ( $c=-0.381, \mathrm{p}<0.05$ ) were observed. At USC, a positive correlation, at $0-10$ and $10-20 \mathrm{~cm}$ depth was observed only in $\mathrm{P}(c=0.615, \mathrm{p}<0.01$ and $c=0.593, \mathrm{p}<0.05$, respectively). At UPA, $\mathrm{K}$ correlated positively in two depths $(c=0.685$, $\mathrm{p}<0.05$ and $c=0.523, \mathrm{p}<0.05$, respectively), while $\mathrm{P}(c=0.793, \mathrm{p}<0.01)$ and clay content $(c=0.532, \mathrm{p}<0.05)$ were significant only at the 10-20 cm layer (Table 4). Major et al. (2005), studying the weed distribution in relation to different soils with different fertility levels, could observe positive correlations between weed density and calcium, magnesium, potassium, phosphorus contents and soil $\mathrm{pH}$. According to Moura et al. (2009), soil fertility influences the weed number and biomass and there are those more demanding than others in certain nutrients.

The relation between the attributes analyzed and the two main weed density in

Table 3 - Spearman correlation coefficient for physical and chemical soil properties in relation to weed density of soil seed bank in at COAGRO (UCO), Santa Cruz (USC) and Paraíso (UPA), plants corresponding to collection from February/March 2010

\begin{tabular}{|l|c|c|c|c|c|c|}
\hline \multirow{2}{*}{} & \multicolumn{2}{|c|}{ UCO } & \multicolumn{2}{c|}{ USC } & \multicolumn{2}{c|}{ UPA } \\
\cline { 2 - 7 } & $(0-10 \mathrm{~cm})$ & $(10-20 \mathrm{~cm})$ & $(0-10 \mathrm{~cm})$ & $(10-20 \mathrm{~cm})$ & $(0-10 \mathrm{~cm})$ & $(10-20 \mathrm{~cm})$ \\
\hline $\mathrm{pH}$ & $-0,029$ & $-0,241$ & $-0,236$ & 0,154 & 0,282 & 0,124 \\
\hline $\mathrm{P}$ & 0,023 & $-0,014$ & 0,356 & 0,034 & $-0,147$ & 0,387 \\
\hline $\mathrm{K}$ & 0,048 & $-0,220$ & $-0,002$ & 0,091 & 0,133 & $0,807^{* *}$ \\
\hline $\mathrm{C}$ & $0,596^{* *}$ & 0,304 & 0,322 & 0,384 & 0,144 & $0,717^{* *}$ \\
\hline CTC & $0,407^{*}$ & 0,169 & 0,256 & 0,402 & 0,210 & 0,476 \\
\hline Sand & $-0,559^{* *}$ & $-0,296$ & $-0,174$ & $-0,328$ & $-0,322$ & $-0,701^{*}$ \\
\hline Silt & 0,002 & 0,112 & 0,101 & 0,119 & 0,175 & 0,144 \\
\hline Clay & $0,481^{* *}$ & 0,304 & 0,065 & $0,651^{* *}$ & $-0,196$ & $0,715^{* *}$ \\
\hline
\end{tabular}

$*$ significant at $5 \%$ probability; $* *$ significant at $1 \%$ probability. 
Table 4 - Spearman correlation coefficient for the physical and chemical properties of soil in relation to the density of weed seed bank in the soil of the plants COAGRO (UCO), Santa Cruz (USC) and Paradise (UPA), during June/July 2010 collection

\begin{tabular}{|l|c|c|c|c|c|c|}
\hline \multirow{2}{*}{} & \multicolumn{2}{|c|}{ UCO } & \multicolumn{2}{c|}{ USC } & \multicolumn{2}{c|}{ UPA } \\
\cline { 2 - 7 } & $(0-10 \mathrm{~cm})$ & $(10-20 \mathrm{~cm})$ & $(0-10 \mathrm{~cm})$ & $(10-20 \mathrm{~cm})$ & $(0-10 \mathrm{~cm})$ & $(10-20 \mathrm{~cm})$ \\
\hline $\mathrm{pH}$ & 0,045 & 0,006 & $-0,335$ & $-0,197$ & $-0,367$ & $-0,319$ \\
\hline $\mathrm{P}$ & $0,412^{*}$ & 0,206 & $0,615^{* *}$ & $0,593^{*}$ & 0,452 & $0,793^{* *}$ \\
\hline $\mathrm{K}$ & 0,265 & 0,234 & 0,124 & 0,377 & $0,685^{*}$ & $0,523^{*}$ \\
\hline $\mathrm{C}$ & $-0,016$ & 0,268 & 0,250 & 0,207 & 0,098 & 0,133 \\
\hline CTC & 0,094 & $0,403^{*}$ & 0,234 & 0,118 & 0,252 & 0,273 \\
\hline Sand & $-0,291$ & $-0,313$ & 0,296 & $-0,156$ & 0,084 & $-0,413$ \\
\hline Silt & $-0,218$ & $-0,381^{*}$ & $-0,362$ & 0,046 & 0,098 & 0,035 \\
\hline Clay & $0,339^{*}$ & $0,475^{* *}$ & $-0,097$ & 0,091 & 0,056 & $0,532^{*}$ \\
\hline
\end{tabular}

$*$ significant at $5 \%$ probability; $* *$ significant at $1 \%$ probability.

each area and in each depth was also verified. During season 1 (Table 5) at UCO, species Oxalis corniculata, prominent at the two depths, correlated significantly only at the $10-20 \mathrm{~cm}$ depth, and negatively with $\mathrm{K}(c=-0.372, \mathrm{p}<0.05)$ and with sand content $(c=-0.349, \mathrm{p}<0.05)$ and it correlated positively with $\mathrm{C}(c=0.340$, $\mathrm{p}<0.05)$. Cyperus rotundus, prominent at the $0-10 \mathrm{~cm}$ depth, was positively correlated with $\mathrm{C}, \mathrm{CTC}$ and with clay content $(c=0.539$, $\mathrm{p}<0.01, c=0.516, \mathrm{p}<0.01$ and $c=0.679, \mathrm{p}<0.01$, respectively) and negatively correlated with sand content $(c=-0.464, \mathrm{p}<0.05)$. Coronopus didymus, prominent at the $10-20 \mathrm{~cm}$ depth, correlated negatively with $\mathrm{pH}(c=-0.459$, $\mathrm{p}<0.05$ ).

At USC, during season 1, of the species that have been prominent at the two depths, only Stemodia trifoliata correlated with the soil properties observed; at the $0-10 \mathrm{~cm}$ depth it correlated positively with clay content $(c=$ $0.447, \mathrm{p}<0.05$ ) and at the $10-20 \mathrm{~cm}$ depth with CTC $(c=0.475, \mathrm{p}<0.05)$. At UPA, Cyperus rotundus correlated positively at the $0-10 \mathrm{~cm}$ layer with $\mathrm{P}(c=0.769, \mathrm{p}<0.01)$ and $\mathrm{K}(c=0.868$, $\mathrm{p}<0.01)$ and at the $10-20 \mathrm{~cm}$ layer with $\mathrm{C}(c=$ $0.691, \mathrm{p}<0.05)$ and CTC $(c=0.701, \mathrm{p}<0.05)$ (Table 5). In this area, species Phyllanthus niruri, prominent at the two depths, correlated only at the $10-20 \mathrm{~cm}$ depth, positively with clay content $(c=0.652, \mathrm{p}<0.05)$ and negatively with sand content $(c=-0.694, \mathrm{p}<0.05)$. Shiratsuchi et al. (2005), aiming to study the correlation between soil properties and SSB, observed a positive correlation between the incidence of Cyperus rotundus, Brachiaria plantaginea and
Commelina benghalensis with $\mathrm{K}$ and a negative correlation with $\mathrm{pH}, \mathrm{Ca}, \mathrm{Mg}, \mathrm{V} \%$ and CTC.

During season 2, at UCO, species Solanum americanum, prominent at the $10-20 \mathrm{~cm}$ layer, showed no significant correlation with soil properties, while Cyperus rotundus, prominent at the $0-10 \mathrm{~cm}$ layer, correlated positively with clay content $(c=0.559, \mathrm{p}<0.01)$ and negatively with sand content $(c=-0.556, \mathrm{p}<0.01)$ (Table 6). Phyllanthus niruri, prominent in both depths, correlated only with clay content $(c=0.365$, $\mathrm{p}<0.05$ ) at the $10-20 \mathrm{~cm}$ depth. At USC, Cyperus rotundus correlated positively with $\mathrm{P}$ in both depths $(c=0.589, \mathrm{p}<0.05$ and $c=0.631, \mathrm{p}<0.01$, respectively). At USC, Cyperus rotundus correlated positively with $\mathrm{K}$ also $(c=0.487$, $\mathrm{p}<0.05)$ at the $10-20 \mathrm{~cm}$ layer and negatively with $\mathrm{pH}$ and silt content $(c=-0.473, \mathrm{p}<0.05$ and $c=-0.549, \mathrm{p}<0.05$, respectively) at the 0 $10 \mathrm{~cm}$ layer (Table 6). Oxalis corniculata correlated positively with silt $(c=0.429, \mathrm{p}<0.05)$ at the $0-10 \mathrm{~cm}$ layer, and with $\mathrm{C}(c=0.644$, $\mathrm{p}<0.01)$ and CTC $(c=0.454, \mathrm{P}<0.05)$ at the $10-$ $20 \mathrm{~cm}$ layer (Table 6). At UPA, Phyllanthus niruri correlated positively with $\mathrm{K}$ at both layers $(c=$ $0.754, \mathrm{p}<0.01$ and $c=0.582, \mathrm{p}<0.05$, respectively) and with $\mathrm{P}(c=0.636, \mathrm{p}<0.05)$ only at the 10-20 cm layer (Table 6). Cyperus rotundus, also prominent at the two layers, correlated positively only with $\mathrm{P}(c=0.519$, $\mathrm{p}<0.05$ ) at the $10-20 \mathrm{~cm}$ layer. Shiratsuchi et al. (2005) found that the higher the P content in the area, the greater the $C$. rotundus density. Iwara et al. (2011) also observed that $P$ influenced in a higher weed density. The authors attributed this result to the fact that 
Table 5 - Spearman correlation coefficient for physical and chemical soil properties in relation to two main weed found in the soil seed bank at COAGRO (UCO), Santa Cruz (USC) and Paraíso (UPA) plants, during February/March 2010 collection

\begin{tabular}{|c|c|c|c|c|c|c|c|c|c|c|c|c|}
\hline & \multicolumn{4}{|c|}{$\mathrm{UCO}$} & \multicolumn{4}{|c|}{ USC } & \multicolumn{4}{|c|}{ UPA } \\
\hline & \multicolumn{2}{|c|}{$(0-10 \mathrm{~cm})$} & \multicolumn{2}{|c|}{$(10-20 \mathrm{~cm})$} & \multicolumn{2}{|c|}{$(0-10 \mathrm{~cm})$} & \multicolumn{2}{|c|}{$(10-20 \mathrm{~cm})$} & \multicolumn{2}{|c|}{$(0-10 \mathrm{~cm})$} & \multicolumn{2}{|c|}{$(10-20 \mathrm{~cm})$} \\
\hline & OXA & CYP & OXA & COR & CYP & STE & CYP & STE & CYP & PHY & CYP & PHY \\
\hline $\mathrm{pH}$ & -0.222 & -0.047 & -0.204 & $0.459^{*}$ & -0.19 & -0.170 & 0.045 & -0.159 & -0.277 & 0.046 & 0.15 & -0.171 \\
\hline $\mathrm{P}$ & -0.249 & 0.302 & -0.085 & -0.015 & 0.338 & -0.007 & 0.231 & -0.301 & $0.769 * *$ & 0.025 & 0.373 & 0.176 \\
\hline K & -0.321 & 0.233 & $-0.372 *$ & -0.269 & -0.155 & 0.123 & 0.188 & 0.055 & 0.144 & 0.161 & $0.868^{* *}$ & 0.373 \\
\hline $\mathrm{C}$ & 0.240 & $0.539 * *$ & $0.340 *$ & 0.132 & 0.100 & 0.077 & 0.170 & 0.357 & -0.067 & -0.007 & $0.691 *$ & 0.359 \\
\hline CTC & 0.045 & $0.516^{* *}$ & -0.117 & -0.128 & 0.166 & 0.339 & -0.210 & $0.475^{*}$ & 0.236 & 0.014 & $0.701 *$ & 0.228 \\
\hline Sand & -0.013 & $-0.464^{*}$ & $-0.349 *$ & -0.204 & 0.055 & -0.409 & -0.038 & -0.271 & -0.085 & -0.056 & -0.320 & $-0.694 *$ \\
\hline Silt & 0.146 & -0.296 & 0.191 & -0.210 & -0.105 & 0.313 & 0.072 & 0.280 & -0.018 & 0.420 & 0.215 & 0.375 \\
\hline Clay & -0.105 & $0.679^{* *}$ & 0.201 & -0.312 & -0.106 & $0.447 *$ & -0.025 & 0.389 & 0.391 & -0.238 & 0.285 & $0.652 *$ \\
\hline
\end{tabular}

OXA - Oxalis corniculata, CYP - Cyperus rotundus, COR - Coronopus didymus, STE - Stemodia trifoliata and PHY - Phyllanthus niruri.

* significant at $5 \%$ probability; ** significant at $1 \%$ probability.

Table 6 - Spearman correlation coefficient for physical and chemical soil properties in relation to two main weed found in the soil seed bank at COAGRO (UCO), Santa Cruz (USC) and Paraíso (UPA), during June/July 2010 collection

\begin{tabular}{|c|c|c|c|c|c|c|c|c|c|c|c|c|}
\hline & \multicolumn{4}{|c|}{ UCO } & \multicolumn{4}{|c|}{ USC } & \multicolumn{4}{|c|}{ UPA } \\
\hline & \multicolumn{2}{|c|}{$(0-10 \mathrm{~cm})$} & \multicolumn{2}{|c|}{$(10-20 \mathrm{~cm})$} & \multicolumn{2}{|c|}{$(0-10 \mathrm{~cm})$} & \multicolumn{2}{|c|}{$(10-20 \mathrm{~cm})$} & \multicolumn{2}{|c|}{$(0-10 \mathrm{~cm})$} & \multicolumn{2}{|c|}{$(10-20 \mathrm{~cm})$} \\
\hline & CYP & PHY & PHY & SOL & CYP & OXA & CYP & OXA & CYP & PHY & CYP & PHY \\
\hline $\mathrm{pH}$ & -0.157 & 0.003 & 0.044 & 0.067 & $-0.473^{*}$ & 0.256 & -0.287 & -0.168 & -0.089 & -0.424 & -0.064 & -0.320 \\
\hline $\mathrm{P}$ & 0.085 & 0.097 & 0.276 & 0.134 & $0.589^{*}$ & -0.286 & $0.631 * *$ & -0.033 & 0.136 & 0.430 & $0.519^{*}$ & $0.636^{*}$ \\
\hline $\mathrm{K}$ & 0.030 & 0.082 & 0.251 & 0.119 & 0.104 & -0.027 & $0.487 *$ & 0.244 & 0.342 & $0.754 * *$ & 0.405 & $0.582^{*}$ \\
\hline C & 0.304 & 0.080 & 0.219 & 0.144 & 0.107 & 0.299 & 0.046 & $0.644 * *$ & 0.059 & 0.124 & 0.170 & 0.204 \\
\hline CTC & 0.224 & 0.029 & 0.294 & -0.015 & 0.331 & -0.220 & -0.058 & $0.454 *$ & 0.071 & 0.296 & 0.18 & 0.315 \\
\hline Sand & $-0.556 * *$ & -0.278 & -0.280 & -0.070 & 0.359 & -0.348 & -0.079 & -0.245 & -0.043 & -0.039 & -0.280 & -0.438 \\
\hline Silt & 0.001 & 0.081 & -0.230 & -0.088 & $-0.549 *$ & $0.429 *$ & 0.007 & 0.107 & 0.053 & 0.123 & 0.388 & 0.035 \\
\hline Clay & $0.559^{* *}$ & 0.254 & $0.365^{*}$ & 0.163 & -0.068 & 0.275 & 0.092 & 0.386 & 0.057 & 0.123 & 0.381 & 0.473 \\
\hline
\end{tabular}

CYP - Cyperus rotundus, PHY - Phyllanthus niruri, SOL - Solanum americanum and OXA - Oxalis corniculata.

* significant at $5 \%$ probability; ** significant at $1 \%$ probability.

$\mathrm{P}$ is a macronutrient and, therefore, very required for most species because it directly influences their growth and development.

Otto et al. (2007) evaluating the correlation of physical and chemical soil properties with emerged BSS weed density, observed that Galinsoga parviflora and Chenopodium album had a greater number of individuals in low sand content, medium clay content and high silt content areas. According to these authors, the relation with soil properties can define and explain why some species are spread throughout the area and others focus on specific points.

\section{Correlation between weed found in the phyto-sociological survey and physical and chemical soil properties}

At UCO, weed density correlated positively with soil properties only during season 1 , with
$\mathrm{P}(c=0.540, \mathrm{p}<0.01), \mathrm{C}(c=0.352, \mathrm{p}<0.05), \mathrm{CTC}$ $(c=0.401, \mathrm{p}<0.05)$ and clay content $(c=0.424$, $\mathrm{p}<0.05$ ) (Table 7). At USC, in both evaluation periods, negative correlation between plant density and $\mathrm{pH}(c=-0.712, \mathrm{p}<0.01$ and $c=-0.626, \mathrm{p}<0.01$, respectively) and positive correlation with CTC $(c=0.525, \mathrm{p}<0.05)$ in season 1 , with $\mathrm{C}(c=0.467, \mathrm{p}<0.05)$ in season 2 , and with $\mathrm{P}$ in both seasons $(c=0.579$, $\mathrm{p}<0.05 c=0.507, \mathrm{p}<0.05$, respectively) were observed. At UPA, negative correlation for $\mathrm{pH}$ in both seasons $(c=-0.711, \mathrm{p}<0.01$ and $c=-0.679, \mathrm{p}<0.05$, respectively) and positive correlations for $\mathrm{K}$ in both seasons $(c=0.690$, $\mathrm{p}<0.05$ and $c=0.585, \mathrm{p}<0.05$, respectively) and for P only in season $2(c=0.516, \mathrm{p}<0.05)$ were also observed. In these areas, $\mathrm{pH}$ remained in the levels between 5.8 and 6.3, which are not considered harmful to plant growth. Otto et al. (2007) observed the $\mathrm{pH}$ influence on the Amaranthus spp. density, where species density 
are disadvantaged at very low $\mathrm{pH}$ and favored by high levels of sand and silt.

The correlations between the density of the two main weed species and soil properties in each area and in each season are presented in Table 8. It was observed that Sorghum hapelense, prominent in season 2 at $\mathrm{UCO}$ and at UPA, as well as species Indigofera truxillensis (prominent in season 2, at USC) and Commelina erecta (prominent in season 1, at UPA), did not correlate their plant density with any of the soil properties studied. The species Rottboellia cochinchinensis, prominent in season 1 in two areas (at UCO and USC), correlated positively only with C ( $c=0.464, \mathrm{p}<0.05)$, at USC (Table 8). Phyllanthus niruri, prominent in season 1, at UPA, correlated positively only with $\mathrm{K}(c=0.711$, $\mathrm{p}<.01)$. Cyperus rotundus was the species that stood out in many situations (it was not between the two main weed species only in season 1, at UPA). At UCO, Cyperus rotundus correlated positively with clay content in both seasons $(c=0.427, \mathrm{p}<0.05$ and $c=0.406$, $\mathrm{p}<0.05$, respectively) and with $\mathrm{P}(c=0.599$, $\mathrm{p}<0.05), \mathrm{C}(c=0.344, \mathrm{p}<0.05)$ and CTC $(c=0.415, \mathrm{p}<0.05)$ only in season 1 (Table 8$)$. At USC, Cyperus rotundus correlated negatively with $\mathrm{pH}$ in both seasons $(c=-0.683, \mathrm{p}<0.01$ and $c=-0.442, \mathrm{p}<0.05$, respectively); it also correlated positively in both seasons with $\mathrm{P}$ $(c=0.545, \mathrm{p}<0.05$ and $c=0.493, \mathrm{p}<0.05$, respectively), in season 1 with CTC ( $c=0.496$, $\mathrm{p}<0.05)$ and in season 2 with $\mathrm{C}(c=0.584$, $\mathrm{p}<0.05)$. At UPA, Cyperus rotundus, prominent only in season 2 correlated negatively with $\mathrm{pH}$

Table 7 - Spearman correlation coefficient for physical and chemical soil properties of soil in relation to weed density found in the phytosociological survey at COAGRO (UCO), Santa Cruz (USC) and Paraíso (UPA) plants, during February/March and June/ July 2010 collections

\begin{tabular}{|c|c|c|c|c|c|c|}
\hline & \multicolumn{2}{|c|}{$\mathrm{UCO}$} & \multicolumn{2}{|c|}{ USC } & \multicolumn{2}{|c|}{ UPA } \\
\hline & Season 1 & Season 2 & Season 1 & Season 2 & Season 1 & Season 2 \\
\hline $\mathrm{pH}$ & 0.174 & 0.114 & $-0.712 * *$ & $-0.626^{* *}$ & $-0.711 * *$ & $-0.679 *$ \\
\hline $\mathrm{P}$ & $0.540 * *$ & 0.049 & $0.579 *$ & $0.507 *$ & 0.461 & $0.516^{*}$ \\
\hline $\mathrm{K}$ & 0.306 & -0.003 & -0.131 & 0.296 & $0.690^{*}$ & $0.585^{*}$ \\
\hline $\mathrm{C}$ & $0.352 *$ & 0.123 & 0.013 & $0.467^{*}$ & 0.214 & 0.128 \\
\hline CTC & $0.401 *$ & -0.071 & $0.525^{*}$ & 0.189 & 0.091 & 0.060 \\
\hline Sand & -0.244 & -0.154 & 0.224 & -0.052 & -0.004 & 0.210 \\
\hline Silt & -0.148 & 0.098 & -0.301 & -0.013 & 0.228 & 0.151 \\
\hline Clay & $0.424 *$ & 0.146 & -0.215 & 0.075 & -0.126 & -0.070 \\
\hline
\end{tabular}

* significant at $5 \%$ probability; ${ }^{* *}$ significant at $1 \%$ probability.

Table 8 - Spearman correlation coefficient for physical and chemical soil properties in relation to two main weed found in the phytosociological survey at COAGRO (UCO), Santa Cruz (USC) and Paraíso (UPA) plants, during February/March and June/ July 2010 collections

\begin{tabular}{|c|c|c|c|c|c|c|c|c|c|c|c|c|}
\hline & \multicolumn{4}{|c|}{$\mathrm{UCO}$} & \multicolumn{4}{|c|}{ USC } & \multicolumn{4}{|c|}{ UPA } \\
\hline & \multicolumn{2}{|c|}{ Season 1} & \multicolumn{2}{|c|}{ Season 2} & \multicolumn{2}{|c|}{ Season 1} & \multicolumn{2}{|c|}{ Season 2} & \multicolumn{2}{|c|}{ Season 1} & \multicolumn{2}{|c|}{ Season 2} \\
\hline & CYP & ROT & CYP & ROT & CYP & ROT & CYP & ROT & CYP & ROT & CYP & ROT \\
\hline $\mathrm{pH}$ & 0.207 & 0.023 & 0.080 & -0.216 & $-0.683 * *$ & -0.287 & $-0.442 *$ & 0.243 & 0.175 & -0.478 & $-0.588^{*}$ & 0.049 \\
\hline $\mathrm{P}$ & $0.599 *$ & -0.190 & 0.243 & 0.090 & $0.545^{*}$ & 0.403 & 0.493* & -0.363 & -0.079 & 0.155 & 0.413 & -0.070 \\
\hline $\mathrm{K}$ & 0.306 & -0.107 & 0.124 & -0.146 & -0.158 & -0.099 & 0.221 & 0.191 & 0.034 & $0.711^{* *}$ & $0.717 * *$ & -0.292 \\
\hline $\mathrm{C}$ & $0.344^{*}$ & -0.326 & 0.353 & 0.169 & 0.017 & $0.464 *$ & $0.584 *$ & -0.139 & 0.345 & 0.293 & -0.023 & 0.050 \\
\hline CTC & $0.415^{*}$ & -0.265 & 0.175 & 0.034 & $0.496^{*}$ & 0.107 & 0.179 & -0.224 & 0.161 & 0.373 & 0.134 & -0.132 \\
\hline Areia & -0.214 & 0.267 & -0.287 & -0.040 & 0.221 & 0.000 & 0.134 & -0.017 & 0.228 & -0.144 & -0.231 & 0.381 \\
\hline Silte & -0.196 & 0.008 & -0.077 & -0.209 & -0.299 & -0.188 & -0.230 & 0.017 & 0.172 & -0.169 & -0.045 & -0.007 \\
\hline Argila & $0.427 *$ & -0.267 & $0.406^{*}$ & 0.228 & -0.205 & 0.215 & 0.105 & 0.017 & 0.433 & -0.338 & -0.112 & 0.231 \\
\hline
\end{tabular}

CYP - Cyperus rotundus, ROT - Rottboellia cochinchinensis, SOR - Sorghum halepense, IND - Indigofera truxillensis, COM Commelina erecta and PHY - Phyllanthus niruri. * significant at 5\% probability; ** significant at 1\% probability. 
$(c=-0.588, \mathrm{p}<0.05)$ and positively with $\mathrm{K}$ $(c=0.717, \mathrm{p}<0.01)$ (Table 8).

Udoh et al. (2007) studying the influence of physico-chemical soil properties in the weed distribution in five different soils in Nigeria, observed that the distribution and occurrence of the dominant species, Tridax procumbens was strongly influenced by 21 soil properties, including $\mathrm{C}, \mathrm{K}$ and high sand content. These authors concluded that this species has the greatest potential for growth and development in a variety of soils and conditions, since of the five areas observed, it was found in four. In the present study, Cyperus rotundus was found in all areas and in the two seasons evaluated and correlated with some soil characteristics such as P, K, C, CTC and high clay content. The results show that this species has a wide range of distribution in several soils of the region and in sugarcane crops, where it inhibits bud break and sugarcane tillering, which results in smaller booths, in infested areas (Oliveira \& Freitas, 2008). Elucidating the factors that contribute to an increased occurrence and distribution of Cyperus rotundus is extremely important in order to elaborate an integrated and efficient management.

Different plants are known to have different requirements, which demonstrate that differences in the distribution and abundance of weed flora in a scenario may indicate the variation of soil properties (Udoh et al., 2007). Soil properties at different levels can influence weed density in the area. When species are slightly favored by some soil property and slightly impaired by other properties, it means that there is a high relation of density of species in areas with different characteristics, that is, the diffusion of that species may occur in different types of soil. However, when the density of some species is strictly related to some soil characteristic, the incidence of that species in the field can be restricted to the existence of that property (Otto et al. 2007).

Weed found in SSB and in phytosociological survey correlated with the chemical and physical soil properties. Clay content influenced positively a greater density in all areas (UCO, USC and UPA) in at least one of the depths (0-10 and 10-20 cm). In contrast, sand content correlated negatively with SSB plant density in the areas analyzed. At UPA, K influenced in a greater SSB weed density at the $10-20 \mathrm{~cm}$ layer. $\mathrm{P}$ correlated positively with SSB weed density in all areas in at least one of the depths. PH had a negative effect on species density obtained through phyto-sociological survey at USC and UPA. Cyperus rotundus, found in the phytosociological survey correlated positively during season 1, with $\mathrm{P}$, at UCO and USC and with $\mathrm{K}$, during season 2, at UPA. Correlations varied according to season, species and area, demonstrating that these relations depend on many different soil and climatic situations where these plants are found.

\section{ACKNOWLEDGMENTS}

At UENF and FAPERJ for financial and logistical support.

\section{LITERATURE CITED}

ALMEIDA, A. C. S. et al. Desenvolvimento vegetativo e produção de variedades de cana-de-açúcar em relação à disponibilidade hídrica e unidades térmicas. Ci. Agrot., v. 32, n. 5, p. 1441-1448, 2008.

BOGUZAS, V. et al. Quantitative and qualitative evaluation of weed seed bank in organic farming. Agron. Res., v. 2, n. 1, p. 13-22, 2004.

DUARTE JÚNIOR, J. B. et al. Dinâmica de populações de plantas daninhas na cana-de-açúcar em sistema de plantio direto e convencional. Semina: Ci. Agr., v. 30, n. 3, p. 595-612, 2009.

EMPRESA BRASILEIRA DE PESQUISA AGROPECUÁRIA - EMBRAPA. Manual de métodos de análises de solo. 2.ed. Rio de Janeiro: 1997. 212 p.

GASTON, L. A. et al. Spatial variability of soil properties an weed populations in the Mississipi Delta. J. Soil Sci. Soc. Am. J., v. 65, n. 2, p. 449-459, 2001.

GOMAA, N. H. Soil seed bank in different habitats of the Eastern Desert of Egypt. Saudi J. Biol. Sci., v. 19, p. 211-220, 2012.

ISAAC, R. A.; GUIMARÃES, S. C. Banco de sementes e flora emergente de plantas daninhas. Planta Daninha, v. 26, n. 3, p. 521-530, 2008. 
IWARA, A. I. et al. Influence of soil physico-chemical properties on the distribution of woody tree/shurb species in South-Southern Nigeria. J. Agric. Sci., v. 2, n. 2, p. 69-75, 2011.

IZQUIERDO, J. et al. Spatial distribution and temporal stability of prostrate knotweed (Polygonum aviculare) and corn poppy (Papaver rhoeas) seed bank in a cereal field. Weed Sci., v. 57, p. 505-511, 2009.

MENDONCA, J. C. et al. Mapeamento das áreas de cana-deaçúcar na região norte fluminense - RJ por uso de técnicas de sensoriamento remoto. Eng. Agríc., v. 31, n. 3, p. 561-571, 2011.

KUVA, M. A. et al. Banco de sementes de plantas daninhas e sua correlação com a flora estabelecida no agroecossistema cana-crua. Planta Daninha, v. 26, n. 4, p. 735-744, 2008.

LOPES, C. A. et al. Comparação entre a composição florística do banco de sementes do solo e da cobertura vegetal em área cultivada com mandioca e leguminosas consorciadas.

Agronomia, v. 38, n. 1, p. 45-51, 2004.

LORENZI, H.. Plantas daninhas do Brasil: terrestres, aquáticas parasitas e tóxicas. 3.ed. Nova Odessa: Instituto Plantarum, 2000. 640p.

MAJOR, J. et al. Weed composition and cover after three years of soil fertility management in the Central Brazilian Amazon: compost, fertilizer, manure and charcoal applications. Weed Biol. Manag., v. 5, n. 1, p. 69-76, 2005.

MOURA, E. G. et al. Incidência de ervas daninhas e atributos do solo em um agrossistema da pré-amazônia, sob efeito da cobertura morta de diferentes combinações de leguminosas em aléias. Sci. Agr., v. 10, n. 1, p. 7-10, 2009.

MONQUERO, P. A. et al. Mapas de infestação de plantas daninhas em diferentes sistemas de colheita da cana-de-açúcar. Planta Daninha, v. 26, n. 1, p. 47-55, 2008.
MÜllER-DOMBOIS, D.; ELLEMBERG, H. Aims and methods of vegetation ecology. New York: J. Wiley, 1974. $347 \mathrm{p}$.

OLIVEIRA, A. R.; FREITAS, S. P. Levantamento fitossociológico de plantas daninhas em áreas de produção de cana-de-açúcar. Planta Daninha, v. 26, n. 1, p. 33-46, 2008.

OTTO, S. et al. A modelling approach using seedbank and soil properties to predict the relative weed density in organic fields of an italian pre-alpine valley. Weed Res., v. 47, p. 311-326, 2007.

PROJETO DE IRRIGAÇÃO E DRENAGEM DA CANADE-AÇÚCAR NA REGIÃO NORTE-FLUMINENSE PROJIR. Síntese dos estudos básicos. Relatório técnico final. Campos dos Goytacazes. 1983. 179 p. Tomo 1. v. 1.

SILVA, J. M. et al. Variabilidade espacial dos atributos físicos em um Latossolo sob plantio direto e preparo convencional no cultivo da soja no cerrado. R. Ci. Agr., n. 50, p. 167-180, 2008.

SHAUKAT, S. S.; SIDDIQUI, I. A. Spatial pattern analysis of seeds of an arable soil seed bank and its relationship with above-ground vegetation in an arid region. J. Arid Environ., v. 57, n. 3, p. 311-327, 2004.

SHIRATSUCHI, L. S. et al. Correlação da distribuição espacial do banco de sementes de plantas daninhas com a fertilidade dos solos. Planta Daninha, v. 23, n. 3, p. 429-436, 2005.

UDOH, B. T. et al. Influence of soil series and physicochemical properties on weed flora distribution at moor plantation Ibadan, Southwestern Nigeria. J. Agric. Social Sci., v. 3, n. 2, p. 55-58, 2007.

WALTER, A. M.; CHRISTENSEN, S.; SIMMELSGAARD, S. E. Spatial correlation between weed species densities and soil properties. Weed Res., v. 42, n. 1, p. 26-38, 2002. 